\title{
공동주택 친환경인증단지의 에너지성능지표 비교분석 연구 The Analysis on Energy Performance Index of the Green Building Certified Apartment Buildings in Korea
}

\author{
김종엽 ${ }^{1} \cdot$ 정윤혜 $^{2} \cdot$ 백혜선 $^{3}$ \\ Jong-Yeob Kim ${ }^{1}$, Yoon-Hye Jung ${ }^{2}$ and Hae-Sun Paik ${ }^{3}$ \\ (Received September 9, 2013 / Revised October 29, 2013 / Accepted October 29, 2013)
}

\begin{abstract}
요 약
2002년에 친환경건축물인증제도가 시행된 이후 많은 인증 수행에도 불구하고 이 제도의 효과분석이나 개선방안 노력이 저조하다. 특히 인증제도에서 에너지성능은 에너지절약설계기준에 있는 에너지성능지표(EPI)로 평가되지만 지금까지 지표에 대한 현황분석이 미비하여 개선에 어려움이 있다. 본 연구에서는 친환경 공동주택 인증단지를 대상으로 에너지성능지표간의 상관관계를 살펴보고 에너지성능지표의 각 부문별 에너지 기본 배점에 따른 점수 현황을 분석하여 지표 개선을 도모하였다. 친환경 공동주택 인증단지의 EPI 평균득점은 약 74.68점, 최소 63.40 점, 최대 90점으로 편차가 큰 것으로 나타났다. 또한 인증지표 중에서 최고의 배점으로 편성된 에너지소비량의 경우, 최대 12점 배점에서 평균 7.04점으로 평균 수준에 머물고 있었다. 향후 에너지소비량 인증지표에서 등급구간의 강화 또는 산출식의 조정 등의 지표 개선이 필요하였다.
\end{abstract}

주제어 : 친환경건축물인증제도, 공동주택, 에너지소비량, 에너지성능지표

\begin{abstract}
Although many certification works have been carried out since Green Building Certification was enforced in 2002, analyses of the effects and efforts to improve this system are still poor. In the certification system, the energy performance was usually assessed by Energy Performance Index(EPI) of the Energy Saving Design Standards for Buildings. However, due to the inadequacy of analyses on current situation of the Index, there are difficulties to reform it. In this research of green-certified apartments, the author examined correlations between energy performance indexes and aimed to improve the Index by analyzing the scores based on point distribution of respective fields. The average EPI score of green-certified apartments was 74.68, and there was wide variations in min 63.4 and max 90. Furthermore, the average score of energy consumption, which was allotted the most points, was 7.04 out of 12 . Therefore, betterments in the Index such as reinforcement in grade ranges and adjustment of the calculation method are necessary.
\end{abstract}

Key words: Green Building Certification, Apartment Buildings, Energy Conservation, Energy Performance Index(EPI)

\section{1. 서 론}

\section{1 연구의 배경 및 목적}

우리나라는 1950년대 이후 산업화와 경제성장으로 인해 생태계가 파괴되고 환경의 질이 크게 악화되었다. 국내의 경 우 온실가스 감축 목표를 설정하여 그에 따른 세부적인 작업 들이 진행되기 시작하였으며, 대표적으로 정부는 건축법 제 65 조에 의거 친환경건축물의 건설유도 및 촉진을 위하여 “친
환경건축물 인증제도”를 2002년부터 운영해오고 있다.

2002년에 친환경건축물인증제도가 시행된 이후 4 개 인증 기관의 인증실적은 총 1,798 건('10.6.30기준)이며, 공동주택 인 증건수는 전체의 $39 \%$ 인 702 건으로, 10 년 이상이 지난 시점 에서 이 제도의 효과분석 및 개선방안 등의 노력이 부족한 상 태이다. 특히 친환경 건축물 인증제도에서 에너지성능은 주 로 건축물 에너지절약설계기준에 있는 에너지성능지표(EPI ; Energy Performance Index)로 평가되고 있다. 하지만 지금까

1) 한국토지주택공사 토지주택연구원 연구위원(주저자: jykimgreen@lh.or.kr)

2) 한국토지주택공사 토지주택연구원 연구원

3) 한국토지주택공사 토지주택연구원 수석연구원(교신저자: hsbaik@lh.or.kr) 
지 에너지성능지표에 대한 현황분석이 미비하여 지표개선에 어려움이 있다.

이에 공동주택 친환경 인증단지에 대한 에너지성능을 보 다 효과적이고 실질적으로 평가하기 위해서는 기 평가된 에 너지성능지표의 개선 항목을 도출할 필요가 있다. 따라서 본 연구에서는 친환경 공동주택 인증단지를 대상으로 에너지성 능지표별 득점현황을 살펴보고 에너지성능지표의 각 부문별 에너지 기본 배점에 따른 점수 현황을 비교분석하여 친환경 건축물인증제도의 에너지소비량 평가지표와 EPI 지표의 개 선사항을 제시하고자 한다.

\section{2 연구방법 및 내용}

조사대상 공동주택 인증단지는 $\mathrm{LH}$ 공사 친환경인증센터에 서 인증을 시행한 2007년 6월부터 2010년 12월까지 본인증 을 받은 공동주택을 대상으로 에너지 항목인 EPI점수를 조사 하였다.

총 200 개의 친환경인증 공동주택의 EPI점수를 수집하였으 며 그 중 175 개의 유효한 EPI점수를 분석에 사용하였다. 조 사된 자료는 SPSS 18.0 을 이용하여 빈도분석, 기술통계, 교 차분석 등을 시행하였다.

EPI 데이터의 구체적인 분석으로는 1)친환경 인증 공동주 택의 물리적 환경(건폐율, 용적율)과 EPI 총점간의 상관관계, 2) 친환경인증 공동주택의 $\mathrm{EPI}$ 각 분야별 평균 점수, 3) EPI 의 각 분야별(건축, 기계, 전기) 에너지 기본 배점에 따른 EPI 점수 현황, 4) EPI의 각 분야별 에너지 인증 항목의 적용 여 부 현황 등이다.

\section{2. 문헌고찰 및 지표 검토}

\section{1 선행연구 고찰}

선행연구는 대부분 친환경 인증제도의 비교분석 및 지표개선 방향에 관련하여 다양한 연구가 이루어졌으나 에너지 평가항목 인 에너지성능지표 현황을 분석하는 연구는 미비하였다. 에너 지성능지표를 중심으로 한 선행연구를 살펴보면 다음과 같다.

이시내 등(2009)의 '국내외 친환경 건축물 인증평가기준의 비교분석을 통한 에너지성능지표 개선방향에 관한 연구'에서 는 우리나라의 경우 개별평가방식을 통하여 에너지성능을 평 가하고 있어 현재 개발되고 있는 에너지절약 건축기술이 평 가항목에 포함되지 않아 점수에 반영되고 있지 않다는 결과 를 얻었다. 박철용과 홍구표(2010)의 사례분석을 통한 공동 주택 에너지성능 평가도구 비교분석'은 다양한 에너지성능 평가도구를 이용하여 인증을 받은 프로젝트를 대상으로 실제 인증사례에 대한 소개 및 요소기술 변화에 따른 에너지성능 평가도구의 등급 영향을 살펴보았다. 그 결과, 단열재 두께를 증가시켜 외피의 열관류율을 향상시키는 방법으로는 에너지
성능 평가도구의 분석결과를 높이는 것은 제한적인 것으로 나타났다. 또한 각 평가도구의 사용방법과 사용범위, 분석결 과의 의미 등이 더 명확하게 정리 될 필요성이 있는 것으로 나타났다. 김광호와 김혜진(2006)의 '에너지성능지표의 개요 와 사례'에서는 친환경 건축물 인증제도의 에너지 부문에서 업무용 건물을 중심으로 에너지성능지표개념과 사례 및 시행 착오에 대하여 살펴보았다.

\section{2 친환경인증제도의 에너지소비량 평가지표}

공동주택 친환경건축물인증제도에서의 에너지소비량 평 가는 최대 12 점 배점으로 구성되어 있으며, 건축물 에너지절 약 설계기준의 EPI 점수를 근거로 평가되어진다. 최소 EPI 60점을 0 점으로 시작하여 EPI 85점일 때 최대 평가점수인 12 점을 받는다. 즉, EPI 60점 이하이면 인허가가 이루어지지 않 으며, EPI 85점 이상에서는 동일하게 평가되고 있다.

당시의 EPI 85점 설정은 정부의 건축물에 대한 중장기적 에너지효율화 2단계 목표치인 현행 에너지소비량 대비 $30 \%$ 절감을 목표로 설정한 것이라 최근에 에너지절약 설계가 강 화됨에 따라 이에 따른 평가지표의 개선이 요구된다.

\section{3 에너지성능지표의 구성}

에너지성능지표는 건축부문, 기계부문, 전기부문, 신재생 에너지부문으로 구분되며, 에너지절약 대상건물은 EPI 부문 별 각 점수를 합산하여 60 점 이상을 취득하여야 한다. 반면 본 연구의 대상 단지에서는 신재생에너지부문이 적용되지 않 았기 때문에 연구범위에서 제외하였다. 구체적인 내용으로는 다음의 표 1 과 같다.

\section{3. 에너지성능지표 분석결과}

\section{1 친환경인증 공동주택의 $\mathrm{EPI}$ 득점현황}

분석대상 친환경 공동주택 인증단지의 EPI 평균은 약 74.68점, 최소 63.40점, 최대 90점이며, EPI득점 간에 편차가 큰 것으로 나타났다. 또한 평균 구간인 EPI 70점에서 80점까 지 획득한 단지가 약 $78 \%$ 를 차지하였으며, 친환경 인증지표 중에서 최고 배점으로 편성된 에너지소비량의 경우 12 점 만 점에서 평균 7.04점으로 평균 수준에 머물고 있었다. 이는 현 재 운영 중인 친환경인증제도의 에너지소비량 산출기준인 최 소 60 점에서 최대 85 점 구간을 벗어나고 있어 산출식의 조정 이 필요하다고 판단된다.

부문별 $\mathrm{EPI}$ 획득점수를 살펴보면, 건축부문의 경우에는 평 균 42.87점, 최소 31.50 점, 최대 50.60점으로 나타났다. 기계 부문은 평균 24.67점, 최소 15 점, 최대 37.96점이며, 전기부문 은 평균 7.14점, 최소 4점, 최대 13점을 나타났다. 각 부문별 최대 배점을 살펴보면, 건축부문이 56점, 기계 46점, 전기 16 


\section{표 1. 에너지성능지표(EPI)의 검토서 내용}

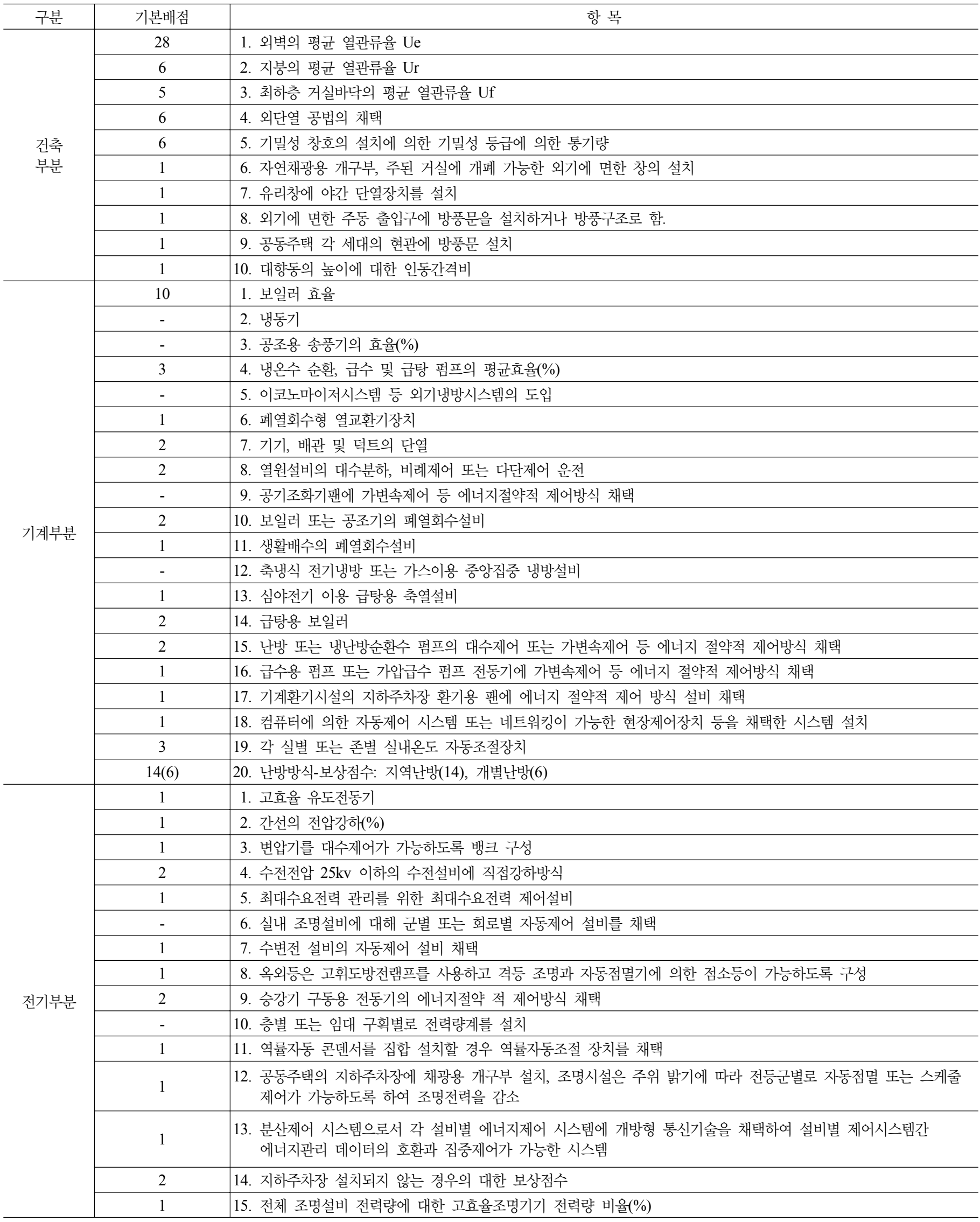


표 2. 친환경 공동주택 인증단지의 EPI 득점 및 각 부문별 점수

\begin{tabular}{c|c|c|c|c}
\hline 구 분 & 최대배점* & 최소값 & 평균 & 최대값 \\
\hline EPI 득점 & $118(110)$ & 63.40 & 74.68 & 90.00 \\
\hline 건축부문 & 56 & 31.50 & $42.87(76.5 \%)$ & 50.60 \\
\hline 기계부문 & $46(38)$ & 15.00 & $24.67(53.6 \%)$ & 37.96 \\
\hline 전기부문 & 16 & 4.00 & $7.14(44.6 \%)$ & 13.00 \\
\hline
\end{tabular}

* 신재생부문(최대배점 10 점) 제외

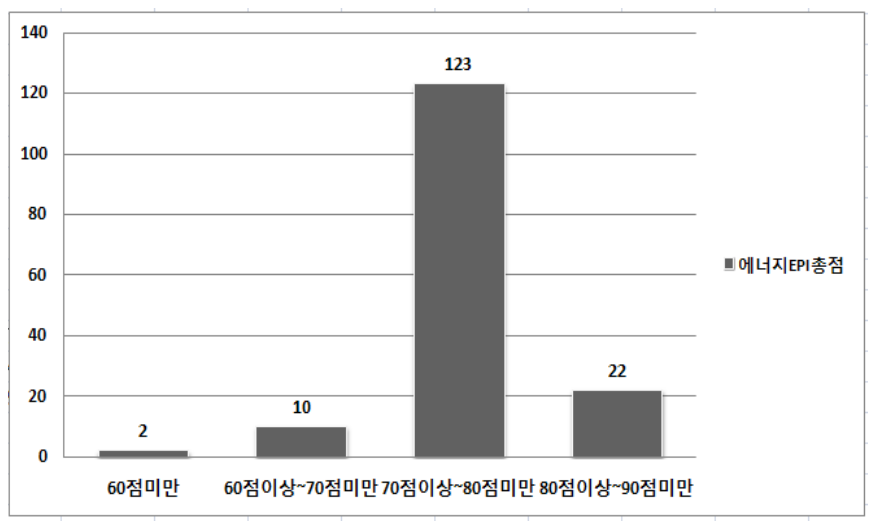

그림 1. $\mathrm{EPI}$ 득점 분포

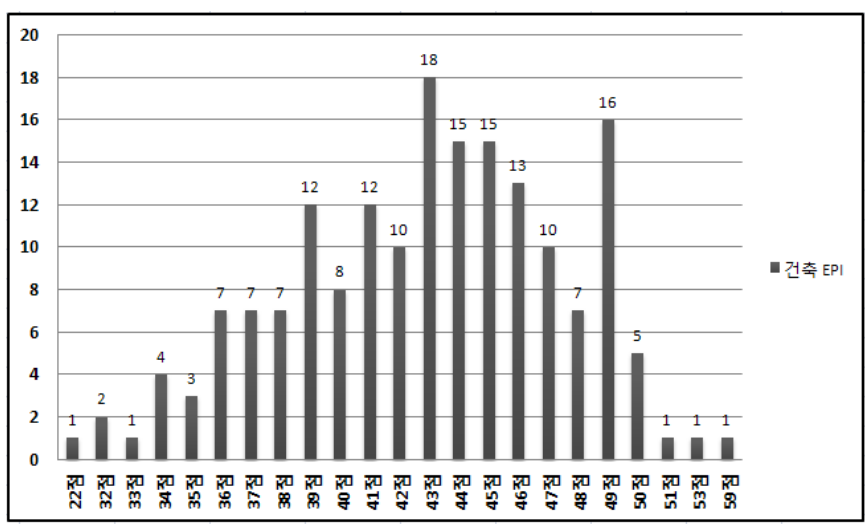

그림 2. EPI 건축부문 득점 분포

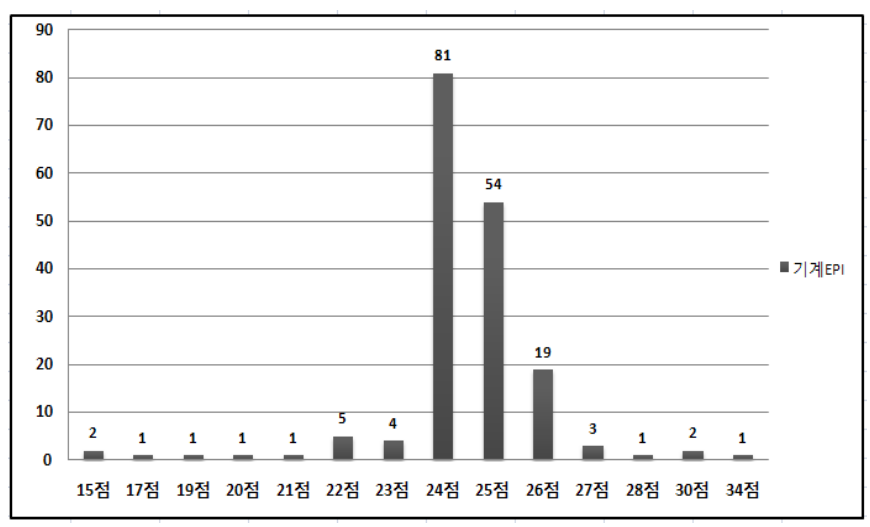

그림 3. EPI 기계부문 득점 분포

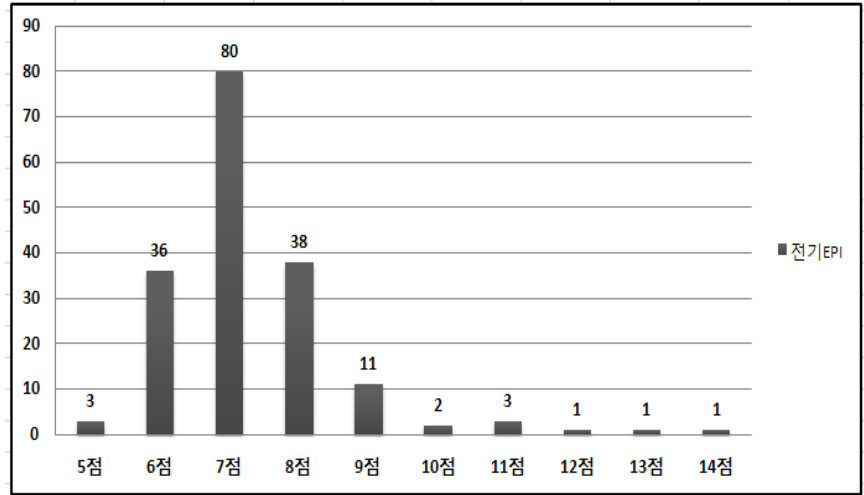

그림 4. EPI 전기부문 득점 분포

점으로 건축부문이 기계, 전기보다 큰 배점을 가지고 있지만, 평균 획득점수로 비교할 경우 건축부문이 $76.5 \%$, 기계 $53.6 \%$, 전기 $44.6 \%$ 수준으로 획득하고 있어 건축부문이 기계, 전기 부문보다 높은 것을 알 수 있다. 이는 공동주택의 경우 기계 및 전기부문에서 적용되지 않은 항목이 건축부문에 비해 상 대적으로 많기 때문이다.

\section{2 각 부문별 기본 배점에 따른 EPI점수}

에너지성능지표 점수는 건축용도에 따라 기본배점(a)이 부 여되고 각 분야별 세부 항목 규정에 따라 배점(b)을 부여 받 게 된다. 즉, 각 부문별 에너지 성능지표는 각 세부 항목별 [기본배점(a) x 평가배점(b)]의 총합으로 계산되어진다. 본 연 구의 범위는 공동주택을 대상으로 하며, 건축용도는 주택1 (공동주택)로 한정하여 조사하였다.

\subsubsection{EPI 건축부문}

건축부문 에너지 성능지표는 1)외벽의 평균 열관류율, 2) 지붕의 평균 열관류율, 3)최하층 거실바닥의 평균 열관류율, 4)외단열 공법의 채택, 5)기밀성 창호의 설치에 의한 기밀성 등급에 의한 통기량 항목의 기본배점(a)과 평가 배점(b)을 통 해 점수를 획득하였다.

외벽의 평균 열관류율 항목은 기본배점(a)이 28점이며 평 가구간에 따라 배점(b) 0.6점, 0.7점, 0.8점, 0.9점, 1점으로 나 뉜다. 외벽의 평균 열관류율에서 최고의 단열수준을 나타내 는 28 점을 획득한 공동주택이 $43 \%$ 정도로 나타났으며, 다음 으로는 22.4점, 25.2점, 16.8점 순으로 나타났다. 또한 외벽의 평균열관류율이 보통 수준이상인 22.4점 이상이 $80 \%$ 정도이 며, 최하의 단열수준인 16.8 점으로 평가된 공동주택도 약 $10 \%$ 를 차지하고 있었다.

최하층 거실바닥의 평균 열관류율 항목은 기본배점(a)이 5 점이며 평가구간 배점(b)에 따라 평가 획득 점수가 달라지며 그 결과, 표 4 와 같다. 대부분의 친환경 인증을 획득한 공동 주택의 $75 \%$ 이상이 보통이상의 단열수준을 나타내는 4점 이 
표 3. 외벽의 평균 열관류율 평가점수

\begin{tabular}{c|c|c|c}
\hline \multicolumn{2}{c|}{ 외벽의 평균 열관류율 } & $\mathrm{N}$ & $\%$ \\
\hline 배점 & 평가점수 & & \\
\hline 0.6 & 16.8 점 & 17 & $9.7 \%$ \\
\hline 0.7 & 19.6 점 & 0 & $0 \%$ \\
\hline 0.8 & 22.4 점 & 32 & $18.3 \%$ \\
\hline 0.9 & 25.2 점 & 31 & $17.7 \%$ \\
\hline 1.0 & 28 점 & 75 & $42.9 \%$ \\
\hline \multicolumn{4}{c}{ 기본배점(a=28), 배점(b=0.6, 0.7, 0.8, $0.9,1)$} \\
\hline
\end{tabular}

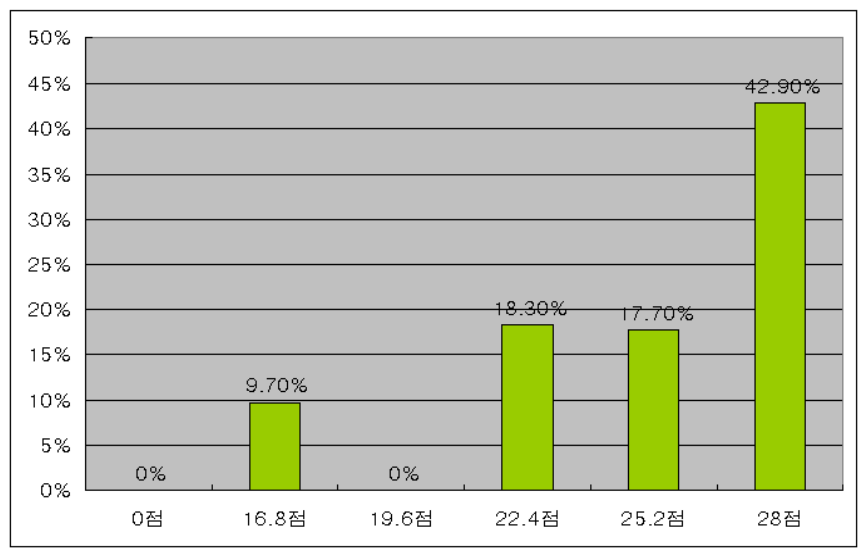

그림 5. 외벽의 평균 열관류율 평가점수

\section{표 4. 최하층 거실바닥의 평균 열관류율 평가점수}

\begin{tabular}{c|c|c|c}
\hline $\begin{array}{c}\text { 최하층 거실바닥의 평균 } \\
\text { 열관류율 }\end{array}$ & $\mathrm{N}$ & $\%$ \\
\hline 배점 & 평가점수 & 1 & $0.6 \%$ \\
\hline 0.6 & 3 점 & 19 & $10.9 \%$ \\
\hline 0.7 & 3.5 점 & 24 & $13.7 \%$ \\
\hline 0.8 & 4 점 & 45 & $25.7 \%$ \\
\hline 0.9 & 4.5 점 & 39 & $22.3 \%$ \\
\hline 1.0 & 5 점 & 47 & $26.9 \%$ \\
\hline \multicolumn{4}{c}{ 기본배점(a=5), 배점 $(\mathrm{b}=0.6,0.7,0.8,0.9,1)$} \\
\hline
\end{tabular}

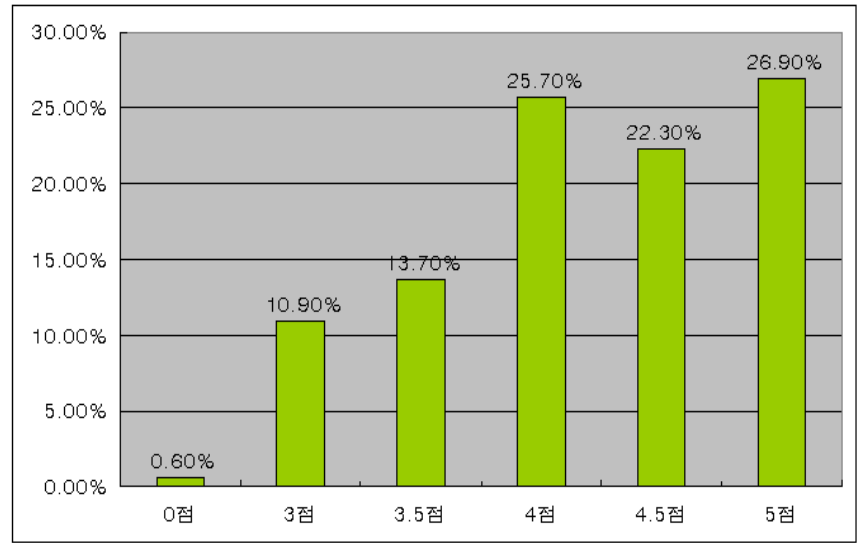

그림 6. 최하층 거실바닥의 평균 열관류율 평가점수
상의 점수를 획득하고 있었으나, 최소수준인 3점도 $10 \%$ 정 도를 차지하였다.

지붕 평균 열관류율, 외단열 공법의 채택, 기밀성창호의 설 치 항목은 기본배점(a)이 6점으로 동일하며 각 항목별 평가 배점(b)에 따라 그 결과 표 5 와 같다. 지붕 평균 열관류율은 보통 이하의 단열수준인 4.2 점이 $40.6 \%$ 로 가장 높은 빈도수 를 나타났으며, 보통수준 이상인 4.8점 이상이 $44 \%$ 정도로 나타 났다. 외단열 공법의 채택은 최소 적용배점인 3.6점이 $61.7 \%$ 로 나타났으며, 반면에 전혀 적용하지 않은 경우가 $35 \%$ 로 나타 났다. 그러나 일부 단지에서는 최고의 배점인 4점을 획득한 단지가 $2 \%$ 정도로 나타나, 200 여 개 조사 대상단지 중 4 개 정 도 단지는 외단열 공법을 적극적으로 적용하였음을 알 수 있 다. 기밀성 창호의 설치 항목은 최고의 배점인 6점(65.1\%)에 서 빈도수가 높게 나타났다. 즉, 친환경 인증을 받는 공동주택 의 경우 지붕 평균 열관류율을 살펴보면 중간 정도의 단열설 계를 하고 있으며, 외단열 공법은 최소한의 적용 수준, 기밀성 창호의 설치는 대부분 우수한 성능의 창호를 채택하고 있다.

대항동의 높이에 대한 인동 간격비에 대한 EPI 점수를 분 석한 결과, 표 6 과 같다. 친환경 인증 대상단지의 인동간격은 인동간격비 1.05 이상 1.10 미만 구간인 0.6 점이 $37 \%$ 를 차지 하였으며, 1.20 이상인 1 점은 $30 \%$ 정도를 차지하는 등 일반 단지에 비해 다소 인동간격비가 크게 나타났다.

\section{표 5. 지붕 열관류율, 외단열 공법, 기밀성 창호 설치 항목의 평가점수}

\begin{tabular}{|c|c|c|c|c|c|c|c|}
\hline \multirow{2}{*}{\multicolumn{2}{|c|}{$\mathrm{EPI}$ 평가 점수 }} & \multicolumn{2}{|c|}{ 지붕평균열관류율 } & \multicolumn{2}{|c|}{ 외단열공법의 채택 } & \multicolumn{2}{|c|}{$\begin{array}{c}\text { 기밀성창호의 } \\
\text { 설치 }\end{array}$} \\
\hline & & $\mathrm{N}$ & $\%$ & $\mathrm{~N}$ & $\%$ & $\mathrm{~N}$ & $\%$ \\
\hline 배점 & 0점 & 1 & $0.6 \%$ & 62 & $35.4 \%$ & 3 & $1.7 \%$ \\
\hline 0.6 & 3.6점 & 25 & $14.3 \%$ & 108 & $61.7 \%$ & 0 & $0 \%$ \\
\hline 0.7 & 4.2점 & 71 & $40.6 \%$ & 1 & $0.6 \%$ & 0 & $0 \%$ \\
\hline 0.8 & 4.8점 & 55 & $31.4 \%$ & 0 & $0 \%$ & 3 & $1.7 \%$ \\
\hline 0.9 & 5.4점 & 18 & $10.3 \%$ & 0 & $0 \%$ & 55 & $31.4 \%$ \\
\hline 1.0 & 6점 & 5 & $2.9 \%$ & 4 & $2.3 \%$ & 114 & $65.1 \%$ \\
\hline
\end{tabular}

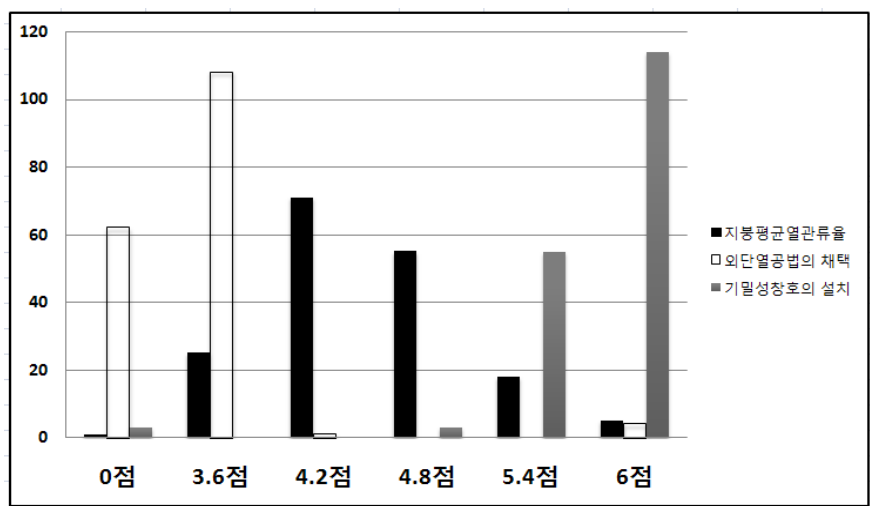

그림 7. 지붕열관류율, 외단열공법, 기밀성 창호설치 항목 평가점수 


\subsubsection{EPI 기계부문}

기계부문 에너지 성능지표에서 1)보일러효율 항목, 4)냉온 수 순환, 급수 및 급탕펌프의 평균효율(\%) 항목은 기본배점 (a)과 평가 배점(b)을 통해 점수를 획득하게 된다.

한편, 6)폐열회수형 열교환기장치, 7)기기, 배관 및 덕트의 단열, 8 )열원설비의 대수분할, 10 )보일러 또는 공조기의 폐열 회수설비, 11)생활배수의 폐열회수설비, 13)심야전기 이용 급 탕용 축열설비, 14)급탕용 보일러, 15)난방 또는 냉난방순환 수 펌프의 대수제어 또는 가변속 제어, 16)급수용 펌프 또는 가압급수펌프 전동기에 가변속제어 등 에너지 절약적 제어방 식채택, 17$)$ 기계환기 시설의 지하주차장 환기용 팬에 에너지 절약적 제어방식 채택, 18)컴퓨터에 의한 자동제어시스템 또 는 네트워킹이 가능한 현장제어장치 등을 채택한 시스템 설 치, 19)각 실별 또는 존별 실내온도 자동조절 장치 설치 항목 은 공동주택 내 적용과 미적용에 따라 점수를 획득하게 된다.

반면, 공동주택에 해당되지 않은 평가 항목으로는 2)냉동 기, 3)공조용 송풍기의 효율(\%), 5)이코노마이저시스템 등 외 기냉방시스템의 도입, 9)공기조화기 팬에 가변속제어 등 에 너지 절약적 제어방식 채택, 12)축냉식 전기냉방 또는 가스 이용 중앙집중 냉방설비(주간 최대냉방부하담당비율, \%)가 있다.

보일러(효율) 항목은 기본배점(a)이 10점이며 평가구간에 따라 배점(b)가 0.6점, 0.7점, 0.8점, 0.9점, 1점으로 나뉜다.

표 6. 대항동의 높이에 대한 인동간격비 항목의 평가점수

\begin{tabular}{c|c|c|c}
\hline \multicolumn{2}{|c|}{ 인동간격비 } & $\mathrm{N}$ & $\%$ \\
\hline 배점 & 0점 & 1 & $0.6 \%$ \\
\hline 0.6 & 0.6 점 & 65 & $37.1 \%$ \\
\hline 0.7 & 0.7 점 & 27 & $15.4 \%$ \\
\hline 0.8 & 0.8 점 & 24 & $13.7 \%$ \\
\hline 0.9 & 0.9 점 & 5 & $2.9 \%$ \\
\hline 1.0 & 1점 & 53 & $30.3 \%$ \\
\hline \multicolumn{4}{|c}{ 기본배점 $(\mathrm{a}=1)$, 배점 $(\mathrm{b}=0.6,0.7,0.8,0.9,1)$} \\
\hline
\end{tabular}

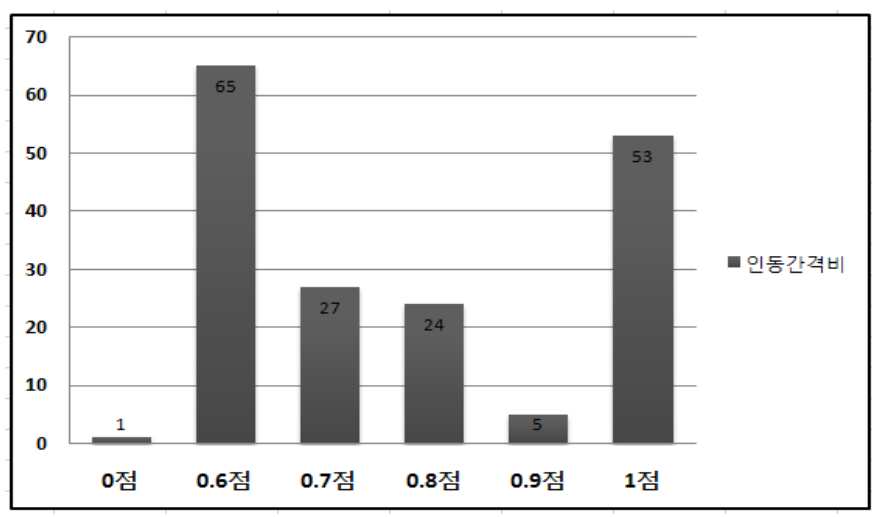

그림 8. 대항동의 높이에 대한 인동간격비 항목의 평가점수
보일러 효율 항목은 지역난방단지가 아닌 경우에 해당되는 경우로 조사 대상단지의 $77 \%$ 이상이 점수를 획득하고 있지 못하고 있다는 것은 역으로 말해서 대부분의 단지가 지역난 방단지임을 알 수 있다. 한편 개별 또는 중앙난방의 경우에 설치하는 보일러 효율은 평가 점수 9점, 10 점을 획득하고 있 어 전반적으로 고효율 보일러를 적용하고 있음을 알 수 있다. 반면 6점, 7점, 8점에서는 점수를 획득하지 못한 구간으로 나 타나, EPI 지표의 개선이 필요한 항목이라 판단된다.

냉온수 순환 및 급수펌프 평균 효율 항목은 조사대상단지 의 난방방식(지역난방, 개별난방) 및 규모에 따라 펌프 종류 가 다양하여 산출에 어려움이 있다. 즉, 펌프 용도와 용량 등 에 의해 가중평균으로 배점을 산정하고 평가점수를 산출하기 때문에 분포 표시가 곤란한 상태이다. 보통 단지내 설치하는 펌프 전체를 고효율 펌프를 적용할 경우 최고 배점인 3 점을 획득하게 되는데, 개별난방단지의 경우 급수펌프만 산출하기 때문에 쉽게 최고 배점을 획득하고 있다.

평가 항목 중 1점 평가 항목인 6)폐열회수형 열교환기장 치, 11)생활배수의 폐열회수설비, 13)심야전기 이용 급탕용 축열설비, 14)급탕용 보일러, 16)급수용 펌프 또는 가압급수 펌프 전동기에 가변속제어 등 에너지 절약적 제어방식채택, 17)기계환기 시설의 지하주차장 환기용 팬에 에너지절약적 제어방식 채택, 18)컴퓨터에 의한 자동제어시스템 또는 네트 워킹이 가능한 현장제어장치 등을 채택한 시스템 설치, 2점

표 7. 보일러(효율) 항목의 평가 점수

\begin{tabular}{c|c|c|c}
\hline \multicolumn{2}{|c|}{ 보일러(효율) } & $\mathrm{N}$ & $\%$ \\
\hline 배점 & 미적용 & 136 & $77.7 \%$ \\
\hline 0.6 & 6점 & 0 & 0 \\
\hline 0.7 & 7점 & 0 & 0 \\
\hline 0.8 & 8점 & 0 & 0 \\
\hline 0.9 & 9점 & 30 & $17.1 \%$ \\
\hline 1.0 & 10점 & 9 & $5.1 \%$ \\
\hline \multicolumn{4}{|c}{ 기본배점 $(\mathrm{a}=10)$, 배점 $(\mathrm{b}=0.6,0.7,0.8,0.9,1)$} \\
\hline
\end{tabular}

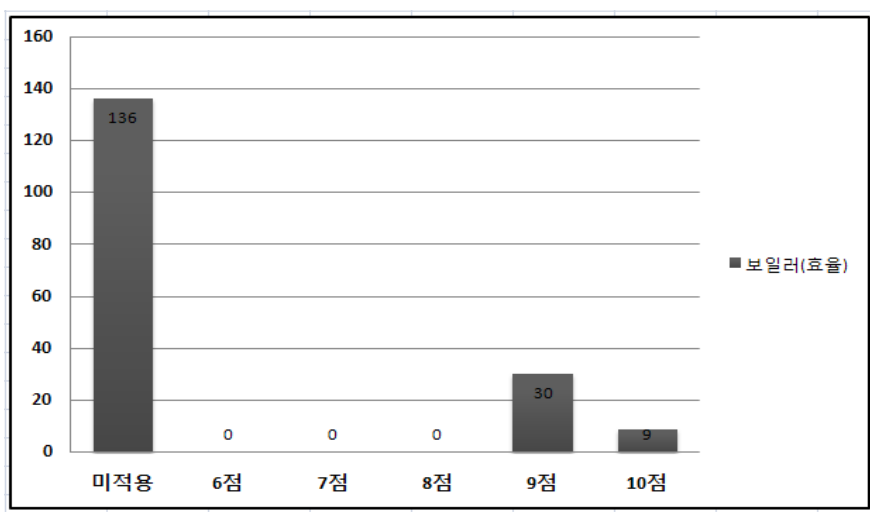

그림 9. 보일러(효율) 항목의 평가점수 
평가 항목인 7)기기, 배관 및 덕트의 단열, 8)열원설비의 대수 분할, 10)보일러 또는 공조기의 폐열회수설비, 15)난방 또는 냉난방순환수 펌프의 대수제어 또는 가변속 제어, 그리고 3 점 평가 항목인 19)각 실별 또는 존별 실내온도 자동조절 장 치 설치 항목의 적용/미적용 현황 및 점수를 살펴보면 다음과 같다.

1점 배점 항목 중에서 6)폐열회수형 열교환기장치 항목의 경우 공동주택의 $72 \%$ 가 적용되지 않았고 $28 \%$ 만 적용되고 있었다. 11)생활배수의 폐열회수설비 및 13)심야전기 이용 급탕용 축열설비 항목의 경우 모든 공동주택에서 적용되고 있지 않은 평가 항목으로 나타나 지표개선이 필요하다. 한편 14)급탕용 보일러 항목은 대부분 미적용으로 나타났지만, 실 질적으로 개별난방단지에만 해당하는 사항이다. 물론 개별난 방단지가 조사대상의 $30 \%$ 정도를 차지하기 때문에 본 항목 의 적용을 표시하는 것이 적합하지만, 대부분 표시를 하지 않 거나 누락하는데서 나타나는 현상이라 판단된다. 나머지 16), $17), 18$ )항목은 $94 \%$ 이상이 공동주택에서 적용하고 있어 변별 력이 다소 떨어지는 지표이다.

2점 평가 항목으로 7)기기, 배관, 덕트의 단열 항목이 $98 \%$ 이상 공동주택에서 미적용 되었으며, 8)열원설비의 대수분 할, 비례제어 또는 다단제어 운전항목에서도 $96 \%$ 이상 공동 주택에서 미적용 되고 있어 지표 개선이 필요하다. 반면 10) 보일러 또는 공조기의 폐열회수설비, 15)난방 또는 냉난방순 환수 펌프의 대수제어 또는 가변속제어 항목은 $75 \%$ 이상 공 동주택에 적용되고 있다.

\section{표 8. 기계부문의 평가 점수}

\begin{tabular}{|c|c|c|c|}
\hline & \multirow{2}{*}{ 평가 항목 } & \multicolumn{2}{|c|}{$\mathrm{N}(\%)$} \\
\hline & & 적용 & 미적용 \\
\hline \multirow{7}{*}{ 1점 } & 6)폐열회수형 열교환기장치 & $49(28 \%)$ & $126(72 \%)$ \\
\hline & 11)생활배수의 폐열회수설비 & $0(0 \%)$ & $175(100 \%)$ \\
\hline & 13)심야전기 이용 급탕용 축열설비 & $0(0 \%)$ & $175(100 \%)$ \\
\hline & 14)급탕용 보일러 & $5(2.9)$ & $170(97.1)$ \\
\hline & $\begin{array}{l}\text { 16)급수용 펌프 또는 가압급수펌프 전동기에 가 } \\
\text { 변속제어 등 에너지 절약적 제어방식채택 }\end{array}$ & 174(99.4) & $1(0.6 \%)$ \\
\hline & $\begin{array}{l}\text { 17)기계환기 시설의 지하주차장 환기용 팬에 } \\
\text { 에너지절약적 제어방식 채택 }\end{array}$ & $170(97.1)$ & $5(2.9 \%)$ \\
\hline & $\begin{array}{l}\text { 18)컴퓨터에 의한 자동제어시스템 또는 네트 } \\
\text { 워킹이 가능한 현장제어장치 등을 채택한 시 } \\
\text { 스템설치 }\end{array}$ & $165(94.3 \%)$ & $10(5.7 \%)$ \\
\hline \multirow{4}{*}{ 2점 } & 7)기기, 배관, 및 덕트의 단열 & $3(1.7 \%)$ & $172(98.3 \%)$ \\
\hline & $\begin{array}{l}\text { 8)열원설비의 대수분할, 비례제어 또는 다단 } \\
\text { 제어 운전 }\end{array}$ & $6(3.4 \%)$ & $169(96.6 \%)$ \\
\hline & 10)보일러 또는 공조기의 폐열회수설비 & $136(77.7 \%)$ & $39(22.3 \%)$ \\
\hline & $\begin{array}{l}\text { 15)난방 또는 냉난방순환수 펌프의 대수제어 } \\
\text { 또는 가변속제어 }\end{array}$ & $173(98.9 \%)$ & $2(1.1 \%)$ \\
\hline 3점 & $\begin{array}{l}\text { 19)각 실별 또는 존별 실내온도 자동조절장 } \\
\text { 치 설치 }\end{array}$ & $173(98.9 \%)$ & $2(1.1 \%)$ \\
\hline
\end{tabular}

3점 평가 항목으로 19)각 실별 또는 존별 실내온도 자동조 절장치 설치는 $99 \%$ 이상이 공동주택에서 적용하고 있어 변별 력이 떨어지며, 지표개선이 요구된다.

\subsubsection{EPI 전기부문}

전기부문 에너지 성능지표에서는 1)고효율 유도전동기, 2) 간선의 전압강하(\%), 15)전체 조명설비 전력량에 대한 고효 율조명기기 전력량 비율(\%) 항목에서만 기본배점(a)과 평가 배점(b)을 통해 점수를 획득하게 된다.

한편, 3)변압기 대수제어가 가능한 뱅크 구성, 4)수전전압 $25 \mathrm{kv}$ 이하의 수전설비에 직접강하방식, 5)최대수요전력 제어 설비, 7)수변전 설비의 자동제어 설비, 8)옥외등은 고휘도방 전램프를 사용하고 격등 조명과 자동점멸기에 의한 점소등이 가능하도록 구성, 9)승강기 구동용 전동기의 제어방식, 11)역 률자동 콘덴서를 집합 설치할 경우 역률자동조절 장치를 채 택, 12)지하주차장 채광용 개구부 설치, 13)분산제어 시스템 으로써 각 설비별 에너지제어 시스템, 14)지하주차장 설치되 지 않는 경우의 보상점수(기계17, 전기12) 항목은 공동주택 내 적용과 미적용에 따라 점수를 획득하게 된다. 반면, 공동 주택에 해당되지 않은 항목으로는 6)실내 조명설비에 대한 자동제어 설비, 10$)$ 층별 또는 구획별로 전력량계 설치 항목 이 있다.

고효율 유도 전동기 항목은 기본배점(a)이 1점이며 평가구 간에 따라 배점(b)가 0.6점, 0.7점, 0.8점, 0.9점, 1점으로 나뉜

\section{표 9. 고효율 유도전동기 항목의 평가 점수}

\begin{tabular}{c|c|c|c}
\hline \multicolumn{2}{c|}{ 고효율 유도전동기 } & $\mathrm{N}$ & $\%$ \\
\hline 배점 & 미제시 & 13 & $7.4 \%$ \\
\hline 0.6 & 0.6 점 & 99 & $56.6 \%$ \\
\hline 0.7 & 0.7 점 & 16 & $9.1 \%$ \\
\hline 0.8 & 0.8 점 & 19 & $10.9 \%$ \\
\hline 0.9 & 0.9 점 & 7 & $4.0 \%$ \\
\hline 1.0 & 1점 & 21 & $12.0 \%$ \\
\hline \multicolumn{3}{|c|}{ 기본배점 $(\mathrm{a}=1)$, 배점 $(\mathrm{b}=0.6,0.7,0.8,0.9,1)$} \\
\hline
\end{tabular}

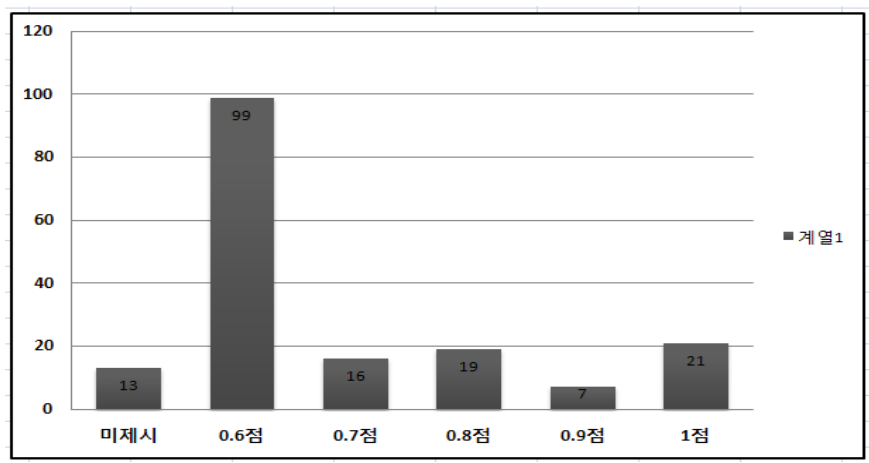

그림 10. 고효율 유도전동기 항목의 평가점수 
표 10. 간선의 전압강하의 평가 점수

\begin{tabular}{|c|c|c|c|}
\hline \multicolumn{2}{|c|}{ 간선의 전압강하 } & $\mathrm{N}$ & $\%$ \\
\hline 배점 & 미제시 & 1 & 0.6 \\
\hline 0.6 & 0.6점 & 28 & 16.0 \\
\hline 0.7 & 0.7점 & 17 & 9.7 \\
\hline 0.8 & 0.8점 & 27 & 15.4 \\
\hline 0.9 & 0.9점 & 2 & 1.1 \\
\hline 1.0 & 1점 & 100 & 57.1 \\
\hline
\end{tabular}

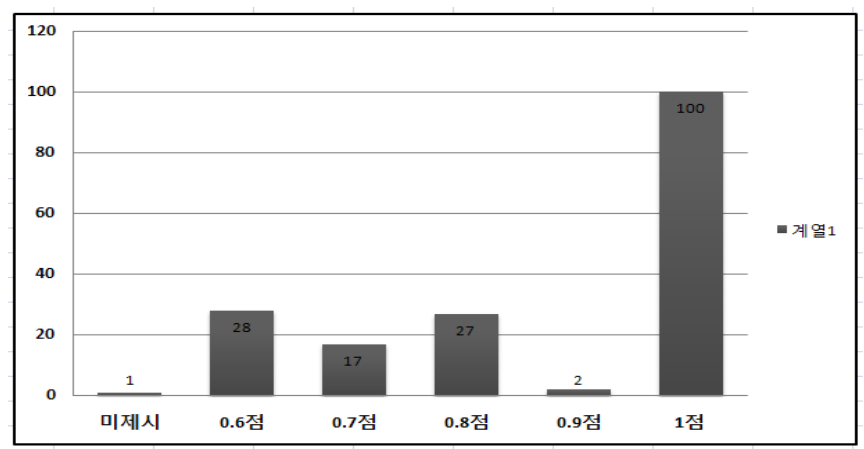

그림 11. 간선의 전압강하의 평가 점수

다. 고효율 유도전동기는 $50 \%$ 이상의 공동주택에서 최소 점 수인 0.6 점을 획득하고 있으며, 다음으로는 1점, 0.8 점, 0.7점, 0.9점 순으로 나타났다.

간선의 전압강하 항목도 고효율 유도전동기와 평가구간이 같으며, $57 \%$ 이상의 공동주택에서 1점을 획득하였다.

한편, 15)전체 조명설비 전력량에 대한 고효율조명기기 전 력량 비율(\%) 항목은 평가점수를 획득한 사례가 없는 것으로 나타났는데, 이는 산출서 제시에 비해 기본배점이 1점에 불과 하기 때문에 제시하지 않는데서 나타나는 현상이라 추측된다.

평가 항목 중 1점 평가 항목인 3)변압기 대수제어가 가능 한 뱅크 구성, 5)최대수요전력 제어 설비, 7)수변전 설비의 자 동제어 설비, 8 )옥외등 고휘도방전램프를 사용하고 격등 조 명과 자동점멸기에 의한 점소 등이 가능하도록 구성, 11)역 률자동 콘덴서를 집합 설치할 경우 역률자동조절 장치를 채 택, 12)지하주차장 채광용 개구부 설치, 13)분산제어 시스템 으로써 각 설비별 에너지제어 시스템, 2점 평가 항목인 4)수 전전압 $25 \mathrm{kv}$ 이하의 수전설비에 직접강하방식, 9)승강기 구 동용 전동기의 에너지 절약적 제어방식 채택, 14)지하주차장 설치되지 않은 경우 보상점수(기계 17 , 전기 12 ) 항목의 적용/ 미적용 현황 및 점수를 살펴보면 다음과 같다.

1점 배점 항목 중에서 3)변압기 대수제어가 가능한 뱅크 구성 항목과 7)수변전 설비의 자동제어 설비 항목은 $25 \%$ 정 도만 적용되었으며, 대부분이 미적용 하였다. 5)최대수요전 력 제어 설비, 11)역률자동 콘덴서를 집합 설치할 경우 역률 자동조절 장치를 채택, 12)지하주차장 채광용 개구부 설치,
표 11. 전기부문의 평가점수

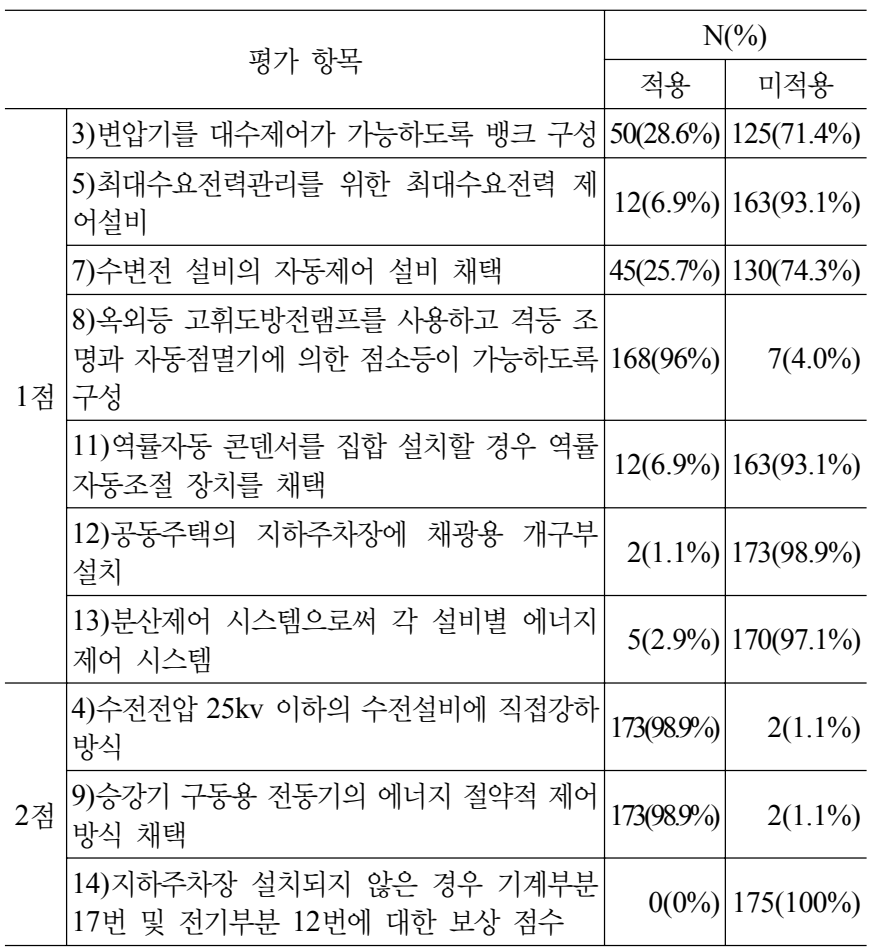

13)분산제어 시스템으로써 각 설비별 에너지제어 시스템 항 목의 경우에는 $93 \%$ 이상 공동주택에서 미적용 되었다. 반면 8)옥외등 고휘도방전램프를 사용하고 격등 조명과 자동점멸 기에 의한 점소등이 가능하도록 구성하는 항목의 경우에는 공동주택 내 $96 \%$ 이상이 적용하고 있었으며, 이는 일반적으 로 적용하는 방식임을 알 수 있다.

2점 평가 항목의 경우 공동주택의 $98 \%$ 이상이 4)수전전압 $25 \mathrm{kv}$ 이하의 수전설비에 직접강하방식을 적용하였고 9)승강 기 구동용 전동기의 에너지 절약적 제어방식을 채택하고 있 어 지표개선이 필요하다. 반면 14)지하주차장 설치되지 않은 경우 보상점수(기계 17 , 전기 12 ) 항목의 경우 $100 \%$ 미적용으 로 나타났는데, 이는 모든 조사대상단지에는 지하주차장이 모두 설치되어 있다는 것을 뜻한다.

\section{4. 결 론}

친환경건축물인증제도는 2002년 이후 많은 인증업무를 수 행했음에도 불구하고 이 제도의 효과분석 및 개선방안 등의 노력이 부족한 상태이다. 특히 친환경 건축물 인증제도에서 에너지성능은 주로 건축물 에너지절약설계기준에 있는 에너 지성능지표(EPI; Energy Performance Index)로 평가되었지만 지금까지 에너지성능지표에 대한 현황분석이 미비하여 지표 개선에 어려움이 있다.

이에 본 연구에서는 친환경 공동주택 인증단지를 대상으 로 에너지성능지표별 득점현황을 살펴보고 에너지성능지표 
의 각 부문별 에너지 기본 배점에 따른 점수 현황을 비교분 석하여 친환경 건축물인증제도의 에너지소비량 평가지표와 $\mathrm{EPI}$ 지표의 개선사항을 제시하였다. 주요 결과를 요약하면 다음과 같다.

1. 친환경 공동주택 인증단지의 EPI 평균은 약 74.68점, 최 소 63.40점, 최대 90점이며, $\mathrm{EPI}$ 득점 간에 편차가 큰 것 으로 나타났으며, 친환경 인증지표 중에서 최고 배점으 로 편성된 에너지소비량의 경우 12 점 만점에서 평균 7.04점으로 평균 수준에 머물고 있었다. 또한 현재 운영 중인 친환경인증제도의 에너지소비량 산출기준인 최소 60점에서 최대 85점 구간을 벗어나고 있어 산출식의 조 정이 필요한 것으로 나타났다.

2. 에너지성능지표 중 건축부문은 평균 42.87점, 기계는 평균 24.67점, 전기는 평균 7.14점으로 나타났다. 각 부 문별 최대 배점은 건축이 56점, 기계 46점, 전기 16 점으 로 건축이 기계, 전기보다 큰 배점을 가지고 있으며, 평 균 득점비율도 건축 $76.5 \%$, 기계 $53.6 \%$, 전기 $44.6 \%$ 수 준으로 건축이 기계, 전기부문보다 높게 나타났다. 이는 공동주택의 경우 기계 및 전기부문에서 적용되지 못하 는 항목이 건축부문에 비해 상대적으로 많기 때문이라 판단된다.
이와 같이 친환경 공동주택의 에너지성능은 전반적으로 평균 수준에 머물고 있는 것으로 나타나, 보다 효과적인 에너 지절약 설계방안을 강구할 필요가 있었으며, 향후 에너지소 비량 인증지표에서 등급구간의 강화 또는 산출식의 조정 등 의 지표 개선이 필요하였다.

\section{감사의 글}

본 논문은 한국토지주택공사 토지주택연구원에서 수행한 “친환경 공동주택 인증단지의 입주자 만족도 조사 및 개선방 안" 연구의 일부분을 정리한 내용입니다.

\section{참고문헌}

1. 국토해양부(2011), 「친환경인증실적 현황 2011년 $1 / 4$ 분기」.

2. 국토해양부(2008), 「친환경건축물 인증기준, 환경부 고시 제 2008-78호, 국토해양부 고시」.

3. 김광호, 김혜진(2006), "EPI(Energy Performance Index)의 개요와 사례”, 「한국설비기술협회지」, 23(7): 56 68.

4. 김종엽, 백혜선, 송옥희, 정윤혜(2011), 「친환경 공동주택 인증단 지의 입주자 만족도 조사 및 개선방안 연구」, LH 토지주택연구원.

5. 박철용, 홍구표(2010), “사례분석을 통한 공동주택 에너지성능 평가도구 비교 분석”, 「한국생태환경건축학회 학술발표대회 논 문집」, $18: 3 \sim 6$.

6. 이시내, 강혜진, 이언구(2009), “국내외 친환경건축물 인증평가 기준의 비교분석을 통한 에너지성능지표(EPI) 개선방향에 관한 연구”, 「대한건축학회 학술발표대회 논문집」, $665 \sim 668$. 